\title{
Low-grade and character-marked hardwoods: A research review and synthesis of solid wood manufacturing and marketing
}

\author{
by David Nicholls ${ }^{1}$ and Matthew Bumgardner ${ }^{2}$
}

\begin{abstract}
There is a substantial body of research from the past half-century addressing hardwood utilization and markets in North America. This synthesis is the first to our knowledge to consider two major (and related) aspects of this research concurrently: low-grade hardwood utilization and marketing of character-marked wood features. We first consider low-grade hardwood resources, products, and key challenges in processing and utilization researched since the 1970s. We then discuss several themes influencing marketing of character-mark products, including product development and consumer and retailer response. This review (considering 119 scientific papers) should help guide future research and value-added utilization of low-grade hardwoods, as it identifies important research results, needs, and gaps yet to be filled. These findings are important in an era of structural changes in the North American hardwood industry and increased pressure to maximize economic value from all hardwood resources.
\end{abstract}

Keywords: low-grade hardwoods, character-marks, value-added hardwoods, industrial wood use, product design, smalldiameter timber, wood perception

\section{RÉSUMÉ}

Une quantité considérable de travaux de recherche a été effectuée au cours des cinquante dernières années sur l'utilisation et les marchés pour les bois de feuillus en Amérique du Nord. Cette synthèse représente à notre connaissance la première étude simultanée des deux aspects les plus importants (et associés) : l'utilisation des bois de feuillus de faible valeur et la mise en marché des caractéristiques des bois avec défauts. Nous avons en premier lieu étudié les ressources en bois de feuillus de faible qualité, les produits et les principaux défis rattachés à sa transformation et son utilisation depuis les années 1970. Nous avons par la suite analysé plusieurs aspects qui influencent la mise en marché de produits de bois avec défauts, incluant le développement de produit ainsi que la réaction des consommateurs et des distributeurs. Cette synthèse (portant sur 119 articles scientifiques) devrait permettre de guider les recherches à venir et la mise en valeur des bois de feuillus de faible valeur marchande, puisqu'elle identifie les résultats de recherche les plus importants, les principaux besoins et les lacunes à combler. Ces résultats ont une importance capitale en cette ère de changements structuraux dans l'industrie du bois de feuillus en Amérique du Nord et alors quaugmentent les pressions pour maximiser la valeur économique de toutes les sources de bois de feuillus.

Mots clés : bois de feuillus de faible valeur, bois avec défauts, bois de feuillus à valeur ajoutée, utilisation industrielle du bois, conception du produit, bille de faible diamètre, perception du bois

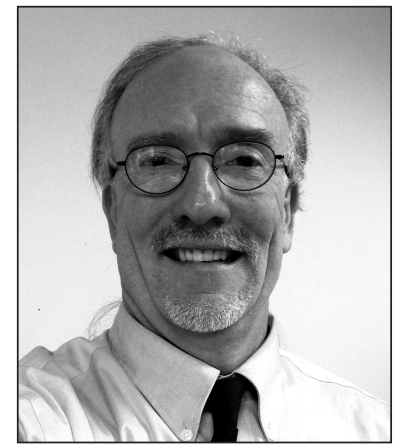

David Nicholls

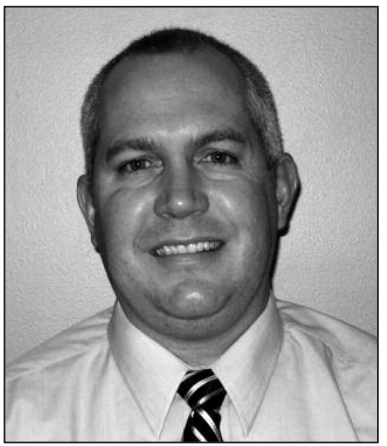

Matthew Bumgardner

\section{Introduction}

Research into improved utilization of low-grade hardwoods has been an important topic to forest products research for decades. Since low-grade lumber constitutes a large proportion of the material contained in most hardwood sawlogs, considerable research effort has been directed at its utilization (Luppold and Bumgardner 2003a). In addition, much research has investigated solid wood alternatives to conventional hardwood lumber when processing low-grade and/or small-diameter hardwoods. Numerous economic feasibility studies have been undertaken to assess these and other potential low-grade production systems (McCay and Wisdom 1984, Lin et al. 1995a, Perkins et al. 2008a; see also Stumbo 1981 for a large compilation of feasibility studies). Koch (1982) pre-

\footnotetext{
${ }^{1}$ U.S. Forest Service, Pacific Northwest Research Station, Sitka, AK; e-mail: dlnicholls@fs.fed.us

${ }^{2}$ U.S. Forest Service, Northern Research Station, Delaware, $\mathrm{OH}$
} 
sented a comprehensive harvesting and mill production system for utilizing small-diameter hardwoods growing on pine sites in the southern United States. Explicit in the work is the desire to produce value-added products (structural panels, aesthetic panels, and Ibeams) rather than lower value products such as pallets and railway ties to help make removal of the low-value material economically viable. Perhaps the number of feasibility studies alone says something of the inherent difficulty in utilizing low-grade hardwoods in higher-grade applications, and developing new manufacturing processes within an established industry and distribution system.

It also has been long understood that consumer and enduser acceptance also is a critical component to low-grade utilization. For example, as early as 1928, Aldo Leopold called for greater use of character-marked wood from a fashion standpoint, stating (pp. 277-278), "Take, for instance, our universal insistence on clear hardwoods for furniture and interior woodwork... Is it too much to hope that fashion may someday lift the ban against sound knots in places where they enhance the beauty of the wood and do not injure strength?" (Leopold 1928). Others have argued that manufacturing considerations have removed the incentive to maintain the character of wood; with the industrialized production of the $18^{\text {th }}$ century came incentive to turn character into waste (Hubbe and Buehlmann 2010). It is this disconnect that research has aimed to bridge by: a.) Finding economical uses for more of the forest resource so that there is a viable incentive to not remove only the very best trees in a given harvest; and, b.) Understanding better the market and human perception factors associated with increasing demand for character-marked products. The objective of this paper is to review and synthesize past research involving the manufacturing and marketing of low-grade hardwoods. Substantial research efforts have focused on both, and understanding this body of work is important in an era of structural changes in the North American hardwood industry and increased pressure to maximize economic value from all hardwood resources.

For the sake of length, this work concerns mostly solid wood manufacturing and products. However, it has been noted that in recent years hardwoods in general (Schuler et al. 2001) as well as specific hardwood species such as poplar and hybrids (Balatinecz et al. 2001, Knudson and Brunette 2015) have realized increased utilization opportunities in the manufacture of various engineered wood products. Furthermore, low-grade hardwoods have long been used in the manufacture of pulp and paper. Recent studies have shown, for example, that the presence of pulpwood markets is an important component to small-diameter harvesting (Bumgardner et al. 2013). Recently, research also has focused on modelling the economic and resource feasibility of using small trees and logging residue in biomass and bioenergy systems (Wu et al. 2011, Thiel et al. 2015). More challenging has been finding economical uses for low-grade material in higher-value wood products.

\section{Methods}

The research considered in this synthesis was obtained from searching a wide range of scientific papers using keyword searches similar to "low grade hardwoods", and "charactermarked wood". We also performed searches to encompass most of the products including character mark features. Therefore, additional search terms such as "secondary manufacturing", "furniture", "cabinets" "lumber, and "knots" were included. We used Google Scholar as the primary search engine. Relevant citations from these works also were pursued and included in this synthesis in a snowball-type procedure.

A few limitations were placed on the search for articles in order for the work to be manageable. For one, trade articles, theses, and dissertations were excluded. Inclusion of these works would greatly expand the required searches, and it was assumed that much of the research covered in these works ultimately appeared in peer-reviewed journal articles. Works general to hardwood utilization and marketing mostly were excluded, unless with substantial focus on low-grade or character-marked material. Lastly, research on the biological and/or silvicultural causes of defects in hardwood material was excluded, although extensive work also exists in this field (Shigo and Hillis 1973, Cutter et al. 2004) as well as in defining hardwood quality (Wiedenbeck et al. 2004).

Although this synthesis includes 119 referenced works, it is possible that relevant articles were missed given the scope of the topic. It is believed, however, that the coverage has been suitable enough for providing a basis for synthesizing lowgrade and character-mark research. Most of the source journals were North America-based; in particular, much of the work in this field historically has been published in the Forest Products Journal (accounting for $44 \%$ of the total citations). The publication dates of all included articles ranged from 1928 to 2015, with a mean of 1998 and a median of 2001. A total of 20 scientific journals are represented, along with several U.S. Forest Service and other technical publications and articles from several Proceedings.

\section{Review and Synthesis}

Fig. 1 shows a conceptual framework describing the synthesis based on themes that emerged from reviewing the literature. The front end, which discusses the hardwood resource and manufacturing systems and considerations, sets the stage for discussion of the marketing opportunities and barriers associated with character-marked hardwoods.

\section{Low-grade hardwood resource}

Low-grade utilization begins with the resource, and resource characteristics are a primary driver making low-grade utilization an enduring research topic. For example, Luppold and Pugh (in press) determined that high-quality sawtimber accounted for just $20 \%$ of the cubic volume of all live hardwood trees in the eastern United States, while 31\% was cull and low-quality sawlog material. There has long been recognition of the importance of low-grade markets to sound hardwood silviculture (Huyler and Turner 1993), and discouragement of poor forest management practices such as diameter-limit harvesting (Fajvan et al. 1998). This also has been a driver of research. As stated by Reynolds and Gatchell (1979, p. 2), "Conventional hardwood markets do not provide enough economic incentive to remove the excess small lowgrade timber so that best forestry practices can be applied." Others have noted that higher value markets often are what drive individual hardwood harvests (Luppold and Alderman 2007). Similarly, Koch (1985) has stated that issues surrounding harvesting are the central problem to utilization of small, poor quality hardwoods growing on pine sites.

Given the importance of resource characteristics, research has addressed this aspect of hardwood utilization. Early work 


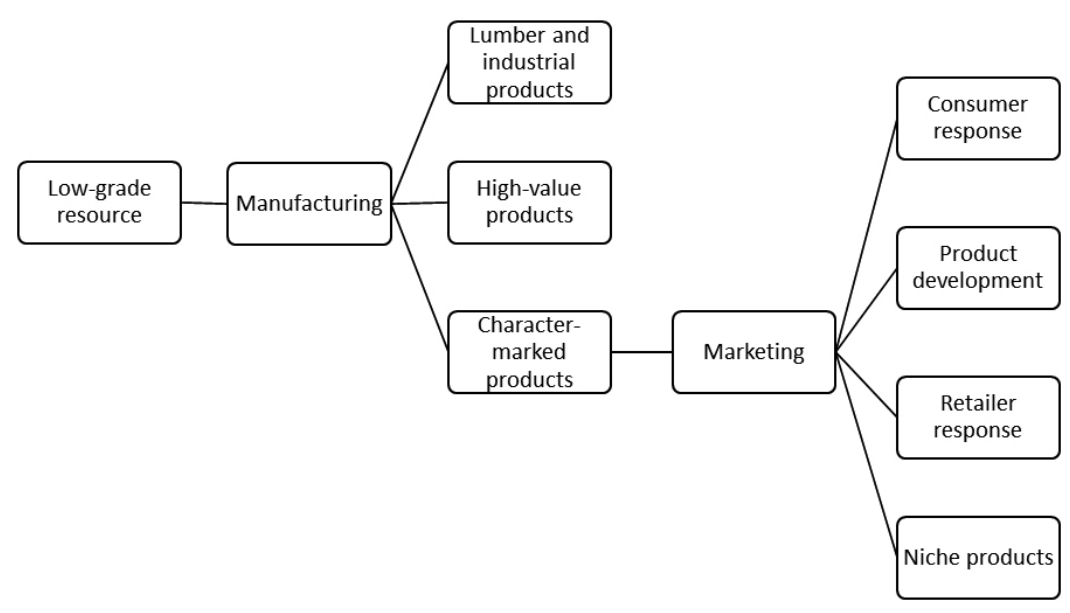

Fig. 1. Conceptual framework of research directed at low-grade hardwood utilization

tion of many of the systems seeking to produce value-added products from low-grade material. Grushecky and Hassler (2012) showed that merchandising hardwood sawlogs from pulpwood delivered to potential pulpwood merchandising yards was not economically feasible under the market conditions they studied.

Other research has provided guidelines for conducting feasibility studies regarding small-diameter hardwood utilization, including discussion of analyses of the resource, yield, economics, and the market (Perkins et al. 2008b). An example of a resource analysis was provided by Alderman et al. (2005), which outlined the increasing volumes of red maple (Acer rubrum L.) in eastern hardwood forests,

focused on better understanding the processing potential and characteristics associated with use of the hardwood roundwood removed in thinnings, in order to encourage better crop tree spacing and productivity (Craft and Baumgras 1978, Baumgras 1980, Baumgras 1992). These earlier works found that the resource at the time contained a large proportion of 40- to 60-year-old trees in need of thinning and other intermediate treatments. This was likely a function of the reforestation that began near the turn of the early 1900s (MacCleary 1996).

An interesting aspect to emerge from this research was that not all Factory Grade 3 sawlogs (as defined by Rast et al. 1973) were equal - that is, those deriving from removals during thinning operations were butt logs (although small), while most conventional Grade 3 logs were upper logs from larger trees. Emanuel (1983) found this to be the case, with higher per unit lumber value being associated with the thinned (butt) logs studied. Later work by Luppold and Bumgardner (2003b) further developed the notion that quality (a physical concept, usually determined by an agreed-upon grading system) and value (an economic concept, determined by supply and demand) are not always necessarily the same concept nor always associated. For example, a species or specific type of material (such as low-grade hardwood) can become more valuable if a production process is developed that can utilize the material. Luppold and Bumgardner (2003b) further showed that most of the hardwood resource is in tree grades that produce low-grade lumber, thus the enduring interest in production and marketing systems to increase its use.

A specific low-grade resource topic that has received considerable research interest is small-diameter material. While much of this work has centered on the need for fire hazard reduction in softwood stands, hardwoods have been studied as well. Bumgardner et al. (2001a), showing that about 93\% to 95\% of the live hardwood trees in the eastern United States were poletimber-sized, conducted a literature review of past small-diameter utilization research efforts and applied diffusion theory to help explain "new" uses of low-grade hardwoods in engineered wood products such as oriented strand board. Diffusion theory also helped explain the limited adop- especially in the smaller diameter classes. It was noted in this work that the red maple resource is distributed primarily in tree grades 3 and lower, which would lead to utilization challenges requiring innovative silvicultural and marketing approaches. Other work has investigated the gas permeability of small-diameter hardwoods as an important factor in pressure treatment of low-grade material (Choong et al. 1974).

\section{Manufacturing of low-grade hardwoods}

No standard definition of what constitutes low-grade exists, thus utilization strategies can vary from mill to mill. For example, work set out to define exactly what constituted lowgrade lumber based on a survey of U.S. hardwood sawmills (Cumbo et al. 2003). It was found that definitions varied, with $37 \%$ of the sample indicating that low-grade was 2 Common and below, 34\% indicating low-grade was 3A Common and below, and $21 \%$ indicating they believed low-grade to be $3 \mathrm{~B}$ Common. Additionally, the study found that many sawmills sold their low-grade lumber to a single market or very few markets, mostly to the pallet industry (55\% of respondents sold lumber to pallet manufacturers). Smith et al. (2004) surveyed secondary hardwood manufacturers in the United States to identify factors influencing decisions to use lowgrade lumber. The most important barrier was found to be the low yield associated with low-grade material, although larger manufacturers utilized lower grade material more than smaller manufacturers.

This section will be broken into three sections, each involving processing research for a specific type of product. These products broadly can be seen as spanning the hardwood supply chain, from traditional lumber to low-value uses of lumber (e.g., pallets and railway ties) to value-added products such as dimension parts for traditional (i.e., defect free) products such as furniture to more novel products making use of character-marked material. Pallets and railway ties are commonly referred to as industrial products (Luppold and Bumgardner 2008) to distinguish them from appearancegrade applications such as furniture, millwork, and cabinets. In addition to using low-grade material, such industrial products also can make use of the log hearts of higher value 
sawlogs (McDonald et al. 1996, Hassler et al. 1999), resulting in more complete utilization of harvested hardwood material.

\section{Lumber and industrial products manufacturing}

Cumbo et al. (2004) conducted a lumber value analysis and market assessment of processing small-diameter (below 10 in. $/ 25 \mathrm{~cm}$ ) oak (Quercus spp.) and hickory (Carya spp.) logs. It was found that wider boards and higher grade boards began increasing at an 8 -inch $(20 \mathrm{~cm}) \log$ diameter, and the increase in unit value was higher for hickory. Voids and unsound areas were found to be the most problematic hardwood lumber defects in the associated market assessment. Serrano and Cassens (1998) found that red oak panels produced from lumber obtained from small-diameter top logs performed practically similar to panels produced from standard grade lumber in terms of dimensional expansion and flatness.

Perkins et al. (2008c) found that about $25 \%$ of the lumber produced by processing red oak small-diameter logs (6 to 10 in./15 to $25 \mathrm{~cm}$ small-end) in a pallet and container part scragg mill was in grade 1 Common, with the remainder in $2 \mathrm{~A}$ and $3 \mathrm{~A}$ Common. Thirty-five percent of the overall yield by weight was in lumber and pallet/container parts, the remainder being chips, sawdust or bark. Red alder (Alnus rubra Bong.) is a hardwood of great economic importance in the Pacific Northwest. Brackley et al. 2009 evaluated lumber recovery from 46-year-old red alder stems harvested near Ketchikan, Alaska, finding wide-ranging grade distributions for lumber from this age class of trees. In this study, roughly $11 \%$ of boards were in the highest (clear) grade, while about $40 \%$ were in lower grades (including the frame grade), indicating the importance of utilizing lower grades of lumber containing knots, bark pockets, and other character features.

Emanuel (1983) found that hardwood logs removed during thinning operations (with diameters from 8 to $11 \mathrm{in} . / 20$ to $27.5 \mathrm{~cm}$ ) yielded $30.2 \%, 19.1 \%$, and $15.1 \%$ of \#1 Common and better lumber for red oak (Quercus rubra L.), hard maple (Acer saccharum Marsh.), and yellow-poplar (Liriodendron tulipifera L.), respectively. In similar work, Rosen et al. (1980) generated several dimension-cutting yield charts for various species and grades by processing low-grade bolt material obtained from stand improvement cuts.

Work with plantation-grown hybrid poplars has shown the potential to produce lumber suitable for appearance grade applications when prairie-grown (Knudson and Brunette 2015). Other species-specific work includes research by Clement et al. (2004) that analyzed the component part distributions possible from sawing lumber from short-length white birch (Betula papyrifera Marsh.) logs. Scholl et al. (2008) developed two experimental kiln schedules with milder drying conditions than the conventional schedule for drying black walnut (Juglans nigra L.) lumber, focusing on lumber cut from small-diameter logs (small-end diameters of $11 \mathrm{in} . / 27.5 \mathrm{~cm}$ or less). An analysis of pre-drying versus postdrying grades found that the modified schedule that lowered the final dry bulb temperature by $20^{\circ} \mathrm{F}$ from the conventional schedule provided the lowest level of defects and grade loss.

A more novel method for sawing small-diameter hardwoods, specifically logs with sweep, is curve sawing. Sweep has been found to be a factor affecting utilization of hardwood poletimber thinnings (Craft and Emanuel 1981). While more common to high production softwood lumber manufacturing, Hamner et al. (2006) studied curve sawing small- diameter hardwood logs with sweep and found that the lumber yield from the outside of curved logs (i.e., outside the pallet cant cut from the centre of the log) increased by $10 \%$ to $12 \%$ when curve sawing hardwood logs with average sweep of $3.3 \mathrm{in} . / 8.3 \mathrm{~cm}$ on a $12-\mathrm{ft}(3.6 \mathrm{~m})$ basis.

Much attention regarding low-grade hardwood utilization research has focused on pallets. Pallets have been the largest single use of hardwood lumber since 1982 (Luppold and Bumgardner 2008), accounting for approximately $38 \%$ of all hardwood lumber consumed in the U.S. in 2008 (Hardwood Market Report 2009). Significant research has thus focused on wood materials use by the pallet industry. For example, Araman et al. (2010) and Bush et al. (2002) highlight a series of studies that were conducted from 1992 to 2006 describing wood use, pallet production, and recycling trends within the industry.

A related research area has been to assess markets and supply chains for wood pallets, or to profile the pallet industry in a given state. One example is a national survey of pallet manufacturers and recyclers conducted by Quesada-Pineda et al. (2012) that investigated aspects of supply chain management practices in the industry. One interesting finding involved a trend toward manufacturers emphasizing shorter lead times and smaller orders from their suppliers, similar to recent trends in the higher value-added sectors of the hardwood industry (described more in the next section). Profiles of the pallet industries in Ohio (Floyd et al. 1993), Pennsylvania (Fraser et al. 1990), Texas (Michael 1997), and Washington (Smith 1991), as well as the southern United States (Dunn et al. 2000), and the entire United States (McCurdy et al. 1988, McCurdy and Phelps 1992, Christoforo et al. 1994) all lend credence to the importance of this market to low-grade hardwood utilization. More recent evidence of the importance of the pallet industry to hardwood utilization was provided by Luppold and Miller (2014) who found that utilization of lowvalue species (for pallets and railway ties) was relatively high during the economic slowdown associated with the housing crisis that began in 2007-2008. In this context, low-grade products can be seen as a critical component of hardwood utilization, providing market diversity to producers when higher value uses might be lagging.

Research also has looked at improving the processing of pallet cants at the mill. For example, Araman et al. (2003) investigated cants at several Appalachian sawmills for unsound defect volumes across four species. While some species differences were detected, splits accounted for the highest percentage of unsound defect volume across species and mills. Decay, bark pockets, shake, and holes also were common defects. While $90 \%$ of the cants had defect volumes less than $10 \%$, the study determined that pre-sorting and some culling of cants prior to pallet part processing could improve pallet quality and service length. Mitchell et al. (2005) proposed a pallet cant grading system based on several yield studies carried out in pallet mills across the eastern United States, ultimately determining that a single cant grade specifying permitted unsound volume would be the most practical and economical approach.

Another product important to low-grade hardwood utilization is railway ties. Railway ties have a long history of hardwood use, playing a critical role in the early transportation system of the United States. Railway ties also are somewhat unique to hardwood products in the importance of 
preservation treatment to their efficient utilization (Burdell 1988). It was not until the early 1900s that railway ties began to be treated; it has been reported that replacing U.S. railway ties on a sustained basis required fifteen to twenty million acres of forestland in 1900 (MacCleery 1996). Although too numerous to discuss here, many published studies over several years have thus investigated the treating, preservation, and disposal/recycling of railway ties. By the end of $20^{\text {th }}$ century, railway ties had an expected service life of 30 to 50 years (Jackson et al. 2001). Wood has several inherent advantages to use in railway ties, including cost competitiveness relative to other materials, light weight, and ease of manufacture and installation (Sonti et al. 1995). Conners (2008) provides an extensive description of the railway tie product and its manufacture and use.

In recent years, railway ties have generally accounted for a percentage in the low teens (nearly $12 \%$ in 2008) of total hardwood lumber consumption (Hardwood Market Report 2009), making them a relatively important component of lowgrade (and overall) hardwood utilization. However, compared to pallets, relatively few studies have been conducted to track wood use by the sector. Phelps and McCurdy (1993) conducted a national survey of U.S. sawmills to ascertain tie production in 1991. Among other results, it was found that $16 \%$ of U.S. sawmills produced railway ties, that $23 \%$ of these mills' production was in railway ties, and that a total of 25 million ties were produced in that year. Most (58\%) were sold by the mills directly to a treatment plant. Other research has shown that at least 12 million ties are replaced annually (Sonti et al. 1995).

\section{High-value products}

An important area of inquiry has involved how to best process low-grade material in the rough mill or sawmill, with the goal of producing higher value products such as furniture and cabinets from low-grade resources. Bumgardner et al. (2001a) provide a review of early manufacturing systems designed to process low-grade hardwoods, including such systems as the SHOLO mill (e.g., Reynolds and Gatchell 1970) and System 6 (e.g., Reynolds et al. 1983). The basic idea behind System 6, for example, was to produce cants at the mill (rather than producing lumber) for direct conversion into furniture parts (edge-glued panels) by secondary processors.

Work also has been undertaken to process low-grade hardwood logs directly into dimension parts. This idea arises from the inherent inefficiency associated with processing such logs with traditional sawmill equipment, which is designed to maximize lumber yield from higher grade logs. Gephart et al. (1995) conducted an extensive review of the advantages and challenges associated with green dimensioning, dating initial interest in the idea in some cases to the 1920s. Bratkovich et al. (2000) conducted a pallet mill study where below-grade red oak logs (representative of pallet and firewood quality material) were converted directly to rough dimension parts. Total yield of pallet and dimension parts was $31 \%$, with $61 \%$ of the product output being clear, defectfree dimension parts and the remaining 39\% being pallet parts. It also was noted that $30 \%$ of the dimension part volume were in lengths at the high end of the cutting bill (used for counter tops for recreational vehicles).

Lin et al. (1994) and Lin et al. (1995b) estimated the potential cutting yield of dimension parts and potential value recovery from converting Grade 2 and Grade 3 red oak sawlogs directly into dimension parts. In addition to system simulation of the impacts of different processing configurations and cutting orders, it was found that Grade 2 sawlogs produced higher dimension yield than did Grade 3 sawlogs. Similar results were obtained by Smith et al. (1996) who found that producing red oak dimension squares directly from logs was most profitable for Prime and No. 1 grade logs but difficult for No. 2 and No. 3 grade logs. Serrano and Cassens (2000) conducted a mill-to-finished-product study to produce glued-up panels from clear parts sorted from the mill's pallet operation when using small top logs (diameters ranging from 7.5 to $13.5 \mathrm{in} . / 18.7$ to $33.7 \mathrm{~cm}$ ). Thirteen percent of the total log weight was converted to clear parts.

\section{Character-marked products}

Hardwood processing decisions can greatly influence the level of character-marks, and therefore the value of lumber products when graded under the National Hardwood Lumber Association's (NHLA) standard rules. For standard NHLA lumber grades, rot stain, knots, splits, ring shake, worm holes, and bird peck are all considered defects (Luppold and Bumgardner 2003a). Primary breakdown, secondary processing, and edging have all been evaluated in terms of the impact that character features have on lumber grade and therefore lumber value. Typically, greater levels of character result in lower grades of lumber when graded according to NHLA standards, with clear defect-free lumber commanding the highest price. One approach is to consider the development of alternate lumber grades for species such as Alaska paper birch (Betula papyrifera var. humilis (Regel) Fernald \& Raup) which tends to contain numerous visual defects and small knots (Nicholls et al. 2004b). The NHLA also has had a character-mark grade on the books that allows for certain visual defects (NHLA 1994), but more recently special grades involving character-marks have been applied more to specific species (NHLA 2014).

Lumber processing decisions have been shown to influence character mark utilization. If character-marks are considered a desirable feature, sawing strategies can be designed to optimize the size and extent of these features. An early study determined potential rough mill yields from low-grade (2A and 2B Common) yellow-poplar lumber. By first ripping yellow-poplar lumber into strips and then crosscutting to remove "objectionable defects", overall yield of charactermarked cuttings was 78\% from 1 Common and 2A Common lumber, and 70\% from 2B Common lumber (Araman 1979). Additionally, relatively long cuttings suitable for use by the furniture industry were obtainable, with $82 \%$ of the 1 Common, $61 \%$ of the $2 \mathrm{~A}$ Common, and $35 \%$ of the $2 \mathrm{~B}$ Common being longer than 50 inches $(125 \mathrm{~cm})$.

Although lumber yields can be greater when charactermark features are included (versus clear cuttings), yield increases can depend on a number of factors, including size of character feature allowed, type of character, lumber grade mix, cutting bill, and number of lumber faces considered. Buehlmann et al. (1998) found that yield increases of eastern hardwoods in rip-first mills were highest when processing 2 Common lumber and allowing character marks up to 2 inches $(5 \mathrm{~cm})$ in diameter on both faces. Similarly, in crosscut first mills, yield was maximized when allowing character features up to 2 inches in diameter in 2 Common lumber 
(Buehlmann et al. 1999). These studies confirm the importance of size of character feature and lumber grade in influencing lumber yield.

In Alaska, birch lumber is often characterized by a high degree of knots, bark pockets, natural stain, and other features typical of small-diameter stems. In addition, the edging strategies used with irregularly shaped flitches can greatly influence cut-stock recovery. Therefore it is very difficult for operators to obtain more than minimal amounts of highvalue clear cuttings. Nicholls et al. (2009) evaluated 143 kilndried birch flitches using the computer simulation program "CORY" (Computerized Optimization of Recoverable Yield) developed at Oregon State University, Corvallis, Oregon, USA. They estimated the cut-stock yield for four different levels of edging severity, finding that cutting yields for parts that included sound character features increased by more than double for most edging strategies. These results indicate that finding value-added alternatives for this character-marked birch could greatly increase the amount of wood produced and speaks to the economic importance of using character marks. A remaining challenge is to use character mark features at strategic levels that consumers' desire.

\section{Marketing of character-marked products}

Character-marks have been defined by the NHLA (p.66) as, ". . . characteristics incident to tree growth," including heartwood, sapwood, knots, burls, swirls/fiber irregularities, bird pecks, holes or grooves, color streaks or spots, and light stain (National Hardwood Lumber Association 1994). Research focusing on character-marks has evolved over the past few decades to include wide ranging applications for secondary wood products that encompass numerous species, product types, and character-mark features. While it is generally recognized that wood is perceived favorably in interior environments (Nyrud and Bringslimark 2010), work related to the use of character-marked wood in such applications has sought to better understand the role specific wood features can play in these perceptions. The research problem centers on the fact that, despite the ubiquitous nature of charactermarked wood, such features have often been deemed unacceptable by secondary wood product manufacturers.

Much of the research in this synthesis has been motivated by identifying higher value markets for lower grade hardwoods containing knots, bark pockets, discolorations, and other visual features. Character-mark research in this area has relied primarily on responses from consumer home shows, trade shows, and similar events. This research has explored the connection between key demographic predictors such as age, gender, household income on consumer preferences and buying tendencies for a wide variety of hardwood products. The following sections discuss character-mark research in terms of visual cues and consumer response, niche products, product development, and retailer perceptions.

\section{Consumer response to character-marked hardwoods}

Visual cues often influence consumer preferences for wood furniture (Ozanne and Smith 1996). Several studies have sought to assess character-marks as a visual cue relative to other furniture attributes in terms of decision-making and information processing. For example, regression analysis was used to assess respondent willingness to pay for furniture pieces when considering eight visual cues (Brinberg et al. 2007). Using Brunswik's lens model, this study found that male and female respondents used different policies for integrating cues for wood furniture perception. These differences translated into preferences for character-marks and natural blemishes for males and grain consistency for females. Further, species differences between oak and cherry (Prunus serotina Ehrh.) furniture were detected. Broman (1995a), using the qualitative approach of grounded theory, found that people perceive wood as a mixture of five feature-properties, including texture, knots, coloration, contrasts, and other properties. Furthermore, this mixture is more important to people's impressions of the wood surface in the absence of a divergent feature such as a large knot; in this case, the divergent feature becomes the defining feature. Broman (1995b) further posited that it was perceptually important for wood surfaces to stimulate interest, and there was a tradeoff between being interesting and harmonious that was manifested in clear versus knotty surfaces. Later work by Broman (2001) followed up with the finding that the degree of "harmony" versus "activity" was important to human perception of wood surfaces, and that people sought a preferred blend of features.

Nordvik and Broman (2007) compared respondents' ratings of actual wood samples versus those displayed digitally on a computer screen where image quality could be adjusted. A key finding of this work was that the property "contrast" was the most important out of six evaluated, and this held for both favorable and unfavorable perceptions. Bigsby et al. (2005) found that color and grain were important wood attributes that could be used to segment consumers based on their wood preferences. In sum, the notion that there is a trade-off between harmony and activity (Broman 2001) seems consistent with the finding that a subset of consumers preferred character-marks and blemishes (male consumers) while another subset preferred grain consistency (female consumers) (Brinberg et al. 2007).

Visual cues also can be evaluated for similar products that exhibit character marks on a pre-determined gradient, with the objective of determining what levels of character are preferred. For example, birch edge-glued panels were evaluated over several different levels of naturally occurring stain, and it was found that for both manufacturers and consumers there were very strong preferences for high levels of natural stain (Nicholls et al. 2010a). Given that light-colored birch sapwood exhibits a high level of contrast to most of the darker character features, this would corroborate other research on the importance of contrast (Nordvik and Broman 2007). Contingent valuation techniques were used to determine consumer willingness to pay a price premium for kitchen cabinet doors made from Alaska birch (Donovan and Nicholls 2003). Here, consumers in Alaska were willing to pay premiums of between USD \$13 and \$43 for their favorite door. In general, doors with greater amounts of character (including knots and color variation) were preferred to products with fewer character features. Conjoint analysis was used to evaluate buying considerations of retailers for oak furniture (Bumgardner et al. 2001b), who found a generally linear preference structure for character-marks based on knot size, with retailers being somewhat neutral toward small knots. Results of this study suggest that opportunities exist for use of small or subtle character-marks in wood household furniture, but as discussed later, retailers generally respond to character-marks differently than consumers. 
Demographic factors such as gender and age can have important bearings on consumer preferences for charactermarked wood products (Jahn et al. 2001). Statistically significant differences between male and female respondents were found among three attributes when rating tongue and groove red alder panels in Alaska markets (Nicholls and Barber 2010). Differences between male and female responses were also found when comparing preferences for different types of character-mark features (Donovan and Nicholls 2003), and as noted earlier, when evaluated using the lens model (Brinberg et al. 2007). Market location can have an important effect on consumer response as well, even between seemingly similar markets. For example, significant differences in consumer preferences have been observed between markets as similar as Anchorage and Fairbanks, Alaska markets that are very close geographically (Nicholls and Barber 2010). Here location was generally more significant than gender in influencing attribute ratings of character-marked wood products.

Responses to hardwood products can be influenced by semantic factors (Blomgren 1965), and whether wood attributes are perceived through word associations or observing an actual sample (Bumgardner and Bowe 2002, Nicholls et al. 2004a, Chen 2012). This can also affect character-mark response. For example, Jahn et al. (2001) showed that species preferences can outweigh the level of character-markings present in cabinet doors in importance to product evaluations.

These studies illustrate the importance of product appearance and demographics on consumer choices for kitchen cabinet doors. Producers of character-marked wood products will need to consider the interaction of species perceptions and willingness-to-pay in determining appropriate marketing strategies for character-marked products. However, as the following sections show, product development and retailer response must also be considered when marketing charactermarked products.

\section{The influence of product development \& design}

Design is clearly a critical component when evaluating secondary hardwood products, often found to be independently important of the wood material used. As stated by Bloch (1995, p. 16), "The physical form or design of a product is an unquestioned determinant of its marketplace success." Conjoint methods were also used to evaluate consumer acceptance in the northeastern United States for chairs manufactured from low-grade hardwood with knots and other character features (Wang et al. 2004). Product design was found to be the most important attribute evaluated (when also considering price, density of character marks, and guarantee policy). Pakarinen and Asikainen (2001) also found design to be the second-most important attribute for evaluating wood household furniture from a list of 15 attributes.

Product design of furniture is a multi-stage process, involving a number of participants and having important implications for hardwood lumber markets. Knowledge of the role of character-marks in this process can help furniture manufacturers better understand their products and develop more effective and successful design concepts. While selection of the wood species used is an important component of furniture product development (Eads 1967, Scholz and Decker 2007), so too can be whether to include charactermarked materials. Both contribute greatly to the fashion aspects of hardwood products. Bumgardner et al. (2001c) developed a 14-stage product development model, finding that few companies considered character-marks in the earliest stages of product development. It was concluded that considering use of character-marks earlier in the product development process, in conjunction with other decisions such as design, species and finish, would lead to greater use. The types and sizes of character marks used also has important implications during the product development process, and the interaction of the marketing and manufacturing functions is critical to development of successful character-mark designs that can be efficiently produced. But before charactermarked products can be presented to consumers, retail buyers play an important "gatekeeper" role in what hardwood products ultimately are offered for sale (Solomon 1988).

\section{The importance of retailer perceptions}

Retailers are an important part of the hardwood supply chain, and their perceptions can differ from those of consumers. Retailers can play a pivotal role in successful product development by identifying important attributes, often early in the process, and communicating product features such as character-marks to consumers (Bumgardner et al. 2000). This is particularly important when considering attributes that consumers have demonstrated a high willingness to pay for. This has been the emphasis for several studies evaluating character features in Alaska birch, a species known for having a wide variety of colorations and other features. Edge-glued panels can be used to create standardized blanks, serving as a versatile material for test marketing. They can be used to create a number of products such as kitchen cabinets, doors, and furniture. Nicholls et al. (2010b) found that retail managers in Alaska generally preferred clear wood as a source for red alder panels, while preferring high levels of natural stain for birch panels. Retailers also recommended providing consumers with a wide variety of offerings - up to 12 standard panel sizes should be provided. Retailers identified several panel attributes as being important, including level of character marks, lack of surface roughness, and good availability. However price was generally ranked less important than product quality.

Bumgardner et al. (2009) used a policy capturing approach (lens model) to assess cues from consumers and retailers when evaluating furniture made from character-marked red alder lumber. These cues were found to differ between consumers and retailers, with character marks, design, and naturalness being important to consumers. None of the investigated cues were significant to retailers, suggesting they were using an entirely different model. Very similar results were obtained by Brinberg et al. (2007) in their furniture study. Lastly, Jonsson et al. (2008) also point out that they found designers to base their evaluations of wood samples on interpretative characterizations, while "laymen" more often used sensory concepts. This underscores the importance of identifying important cues that different members of the supply chain find important.

Similar results have been found for do-it-yourself (DIY)type products. Swearingen et al. (1998) found that consumers were generally more accepting of knots in maple than was expected by professional home centre buyers evaluating the same wood samples, while Marchal and Mothe (1994) reached a similar conclusion for character-marked oak. Consistent with Broman (1995a), it also was found that an even 
dispersion pattern of the knots was important to consumer acceptance.

Retail managers play a vital role in the product development process. Successful product introduction, development, and promotion require close communication and feedback between consumers, retailers, and wood products producers to ensure that the desired features are included. Thus it is important in product promotions to correctly assess these features.

\section{Niche products and character-marks}

Research has pointed to a number of niche opportunities for character-marked products outside of traditional large-scale production operations and markets. Lumber containing character features is often an integral part of the cuttings from small-production sawmills typically owned and operated by individuals or families. These mills usually process a variety of species and log sizes, often driven by timber availability. Thus, it is not uncommon for small sawmills to produce large proportions of slabs, edgings, and miscellaneous cuttings. Opportunities exist for small sawmills, as well as those having low lumber recovery factors, to benefit from strategies to produce higher value niche products. In rural communities, niche markets can play a large role in economic development. For example, the birch craft industry in Alaska likely has the highest board foot value of hardwood lumber in the state (Braden and Nicholls 2004).

In some cases, high value specialty markets can be created for small irregularly shaped cuttings, and from birdseye and other figured grain patterns (Bragg 2007). Species containing inherently high proportions of character-mark features can be used for lumber production, with slabs and edgings providing feedstocks to stimulate a craft industry (Braden and Nicholls 2004). This research found that the average firm size of these family businesses was about two employees, and in some cases raw materials consisted entirely of sawmill residues. A challenge for niche producers using character-marked wood is to find consistent ways to manufacture diverse features such as knots, bark pockets, and naturally occurring stain, and to match these to consumer preferences for high value products. Niche markets also can be created by intentionally creating character-marked products, such as by adding pigments via fungi to create spalting and other unique colorations of wood (Robinson et al. 2011). Another example of intentional character-marking includes physically "distressing" wood by adding dents, holes, or other markings to add to the rustic look of the wood used in certain styles.

\section{Current state of knowledge-ways to increase use of character- marks}

This synthesis identified several themes that researchers favored within the general topic area of character-marked wood. "Low-grade resource", "manufacturing", and "marketing" were all general themes containing numerous publications (Table 1). These general themes all contained at least three sub-themes. Of the 119 papers reviewed, the "manufacturing" theme accounted for the greatest number of papers (55.5\%), followed by "low-grade resource" (17.6\%), and "marketing" (15.1\%). "Other" papers (11.8\%) included useful information for the synthesis but did not fit into the main themes.
Understanding consumer response to character-marked products is clearly important, and much research has looked at this aspect. While attributes such as "harmony" versus "activity" generally, and specific product attributes such as knot-size have been addressed, differences in gender, regional, and even species and designs used in furniture product make generalization difficult. However, it can be said that several studies have shown that consumers, at least in research settings, have shown a preference for charactermarked hardwoods at some level. Another important point from several studies is that features such as design and species are often found to be more important to product perceptions than are character-marks.

Significantly, little is known about retailer perceptions of character-marked products, in spite of their importance in the supply chain. Studies comparing consumers and retailers directly have shown that these groups use different cues for forming judgements about character-marked furniture. Furthermore, the cues used in these studies seem better suited to consumers, as none have been significant for retailers. Therefore an important question that remains is to better understand the cues retailers are using, and how this might influence the willingness to carry character-marked lines on their showroom floors. Limited results to date have shown a propensity for retailers to favor fewer or no marks, likely a function of the uncertainty of consumer response to such products in actual retail settings.

However, niche opportunities are available for charactermark use in higher value products such as furniture and cabinets, even though relatively small volumes of lumber may be required. In such cases supply chains are shortened, i.e., consumers might interact and communicate directly with woodworkers, which overcomes the consistent theme from research that retailers often perceive of character-marked products differently (and usually less favorably) than consumers. Supply chains are especially relevant for many furniture products in the current marketplace, given that much

Table 1. Papers reviewed in synthesis, addressing low-grade and character-marked wood (categorized by thematic area)

\begin{tabular}{lcc}
\hline Theme & Number of publications & Percent of total \\
\hline $\begin{array}{l}\text { Low-grade resource } \\
\text { Low-grade }\end{array}$ & 10 & \\
Oak & 8 & 8.4 \\
$\quad$ Small-diameter & 3 & 6.7 \\
Manufacturing & & 2.5 \\
$\quad$ Furniture & 19 & \\
Pallets & 16 & 16.0 \\
Processing & 15 & 13.4 \\
Lumber/dimension & 7 & 12.6 \\
Railway ties & 7 & 5.9 \\
$\quad$ Cabinets & 2 & 5.9 \\
Marketing & 14 & 1.7 \\
$\quad$ Consumer preferences & 2 & 11.8 \\
Retailers & 2 & 1.7 \\
Product Development & 14 & 1.7 \\
Other & $\mathbf{1 1 9}$ & 11.8 \\
\hline TOTAL & & $\mathbf{1 0 0}$ \\
\hline
\end{tabular}


furniture production is now located outside of North America. Inclusion of character-marks in a given furniture line might be especially challenging when the manufacturing and marketing/design functions are not co-located throughout the product development process (Bumgardner et al. 2001c). Overall, shorter and simpler supply chains likely enhance opportunities for character-mark use.

Another approach beyond niche marketing, which could offer more widespread low-grade lumber use, is to offer character-marked wood as part of a customization strategy. In such a scenario, consumers can choose character-marked wood along with other product features such as species and finish, each representing a different price-point. The authors have witnessed this approach being carried with several Amish-based furniture products. Anecdotally, charactermarked cabinet lines also are observable in many "big box" retail outlets in today's marketplace. Here too, however, these lines typically are shown alongside many other wood types, species, and styles as part of a customized product offering common to cabinet products (Lihra et al. 2008, Luppold and Bumgardner 2009).

At the heart of character-mark use is to understand the continually changing demographics and fashion tastes of the consumer, sometimes fickle and sometimes showing different preferences within relatively small geographic regions. Working directly with consumers or offering character-marked wood as a specific product feature as part of a customization strategy seem to offer the greatest opportunities for valueadded use of low-grade hardwoods in today's marketplace. Further research could investigate the role of design in such character-mark applications, given its importance to product evaluation. For example, it would be interesting to quantify the potential value added by designers' use of charactermarked wood in specific configurations in a given furniture piece.

\section{Conclusion}

A greater understanding of two major aspects of hardwood research-low-grade utilization and marketing of charactermarked products-has important implications for the production, product development, and ultimately profitability, of hardwood firms. One thing that becomes clear when synthesizing the literature from the past 30 years is that profitable utilization of low-grade material in higher value products is not without challenges. In recognition of this, entirely new manufacturing processes have been proposed and introduced through the years, with one of the greatest barriers to adoption being to overcome established practices and distribution channels. Given the characteristics of the hardwood resource however, it is clear that this lower value material has an important role to play in hardwood value chains, and interest in further development of high-value uses remains today and likely will continue into the future. As noted in Bumgardner et al. (2001a), elements of proposed value-added systems are used in practice today, mostly through modified adoption of portions of the systems.

Certain industrial products, such as pallets and railway ties, are historically important products effectively utilizing low-grade material. These products have thus garnered much research attention with notable advancements in production, design, preservation, and recycling/reuse. Going forward, challenges such as phytosanitation requirements to prevent the spread of invasive exotic pests (with much recent research occurring but not covered in this synthesis) and continued competition from non-wood substitutes will be issues faced by the industrial segment of the hardwood industry. New opportunities for low-grade hardwood use related to engineered wood products have increased in importance in recent years, most notably in terms of increased regional opportunities for products that can use a wider variety of hardwood species.

Beyond systems designed to efficiently derive clear wood parts from low-grade material, another approach is to develop markets that make use of the natural visual variability inherent to wood. Correspondingly, much research also has centered on development and market assessment of character-marked products. Character-marks have been shown to have an important impact on product appearance and value for a wide range of hardwood species and products. This is significant in that character-mark type, size, intensity, and other attributes can influence consumer (and retailer) preferences and willingness to pay. In traditional manufacturing systems, character-mark features are integral to all areas of the product development process, including primary and secondary production, product design, and marketing. Perhaps the best opportunities to utilize character-marks in the current marketplace are to offer them as part of a customization strategy or in niche products.

\section{References}

Alderman, D.R., M.S. Bumgardner and J.E. Baumgras. 2005. An assessment of the red maple resource in the Northeastern United States. North. J. Appl. For. 22(3): 181-189.

Araman, P.A. 1979. To make long character-marked cuttings from low-grade yellow-poplar lumber-rip first. Int. J. Furniture Res. 1(10): 14-17.

Araman, P.A., R.J. Bush and E.B. Hager. 2010. U.S. wood pallet material use trends. In: A. Teischinger, M.C. Barbu, M. Dunky, D. Harper, G. Jungmeier, H. Militz, M. Musso, A. Petutschnigg, A. Pizzi, S. Wieland, and T.M. Young. Proceedings, Processing Technologies for the Forest and Biobased Products Industries, Salzburg University of Applied Sciences, Austria, 7-8 October 2010. pp. 208-210.

Araman, P.A., M.F. Winn, M.F. Kabir, X. Torcheux and G. Loizeaud. 2003. Unsound defect volume in hardwood pallet cants. Forest Prod. J. 53(2): 45-49.

Balatinecz, J.J., D.E. Kretschmann and A. Leclercq. 2001. Achievements in the utilization of poplar wood-guideposts for the future. Forest. Chron. 77(2): 265-269.

Baumgras, J.E. 1980. Biomass yields from Allegheny hardwood thinning. Research Paper NE-466. USDA Forest Service, Broomall, PA. 7 p.

Baumgras, J.E. 1992. Effects of silvicultural prescriptions and roundwood markets on the economic feasibility of hardwood thinnings. In: Proceedings of the Twentieth Annual Hardwood Symposium, Cashiers, NC, 1-3 June 1992. pp. 131-142. Hardwood Research Council, Memphis, TN.

Bigsby, H.R., C. Rai and L.K. Ozanne. 2005. Determining consumer preference for furniture timber. J. For. Prod. Business Res. Vol. 2, Article 2, $20 \mathrm{p}$.

Bloch, P.H. 1995. Seeking the ideal form: Product design and consumer response. J. Marketing. 59(3): 16-29.

Blomgren, G.W., Jr. 1965. The psychological image of wood. Forest Prod. J. 15(4): 149-151. 
Brackley, A.M., D. Nicholls and M. Hannan. 2009. An evaluation of the grades and value of red alder lumber in southeast Alaska. Gen. Tech. Rep. PNW-GTR-774. Portland, OR. U.S. Department of Agriculture, Forest Service, Pacific Northwest Research Station. 27 p. Braden, R. and D. Nicholls. 2004. Alaska birch crafts and gifts: Marketing practices and demographics. Forest Prod. J. 54(9): 1-4. Bragg, D.C. 2007. Potential Contributions of Figured Wood to the Practice of Sustainable Forestry. J. Sustain. Forest. 23(3): 67-81.

Bratkovich, S.M., J.S. Gephart, P. Peterson and R.H. Bartz. 2000. Green dimensioning below-grade red oak logs: A Minnesota case study. Forest Prod. J. 50(2): 65-68.

Brinberg, D., M. Bumgardner and K. Daniloski. 2007. Understanding perception of wood household furniture: Application of a policy capturing approach. Forest Prod. J. 57(7/8): 21-26.

Broman, N.O. 1995a. Visual impressions of features in Scots pine wood surfaces: A qualitative study. Forest Prod. J. 45(3): 61-66.

Broman, N.O. 1995b. Attitudes toward Scots pine wood surfaces: A multivariate approach. Mokuzai Gakkaishi. 41(11): 994-1005.

Broman, N.O. 2001. Aesthetic properties in knotty wood surfaces and their connection with people's preferences. J. Wood Sci. 47(3): 192-198.

Buehlmann, U., J.K. Wiedenbeck and D.E. Kline. 1998. Charactermarked furniture: Potential for lumber yield increase in rip-first rough mills. Forest Prod. J. 48(4): 43-50.

Buehlmann, U., J.K. Wiedenbeck and D.E. Kline. 1999. Charactermarked furniture: Potential for lumber yield increase in crosscutfirst rough mills. Forest Prod. J. 49(2): 65-72.

Bumgardner, M. and S. Bowe. 2002. Species selection in secondary wood products: Implications for product design and promotion. Wood Fiber Sci. 34(3): 408-418.

Bumgardner, M.S., R.J. Bush and C.D. West. 2000. Beyond yield improvement: Selected marketing aspects of character-marked furniture. Forest Prod. J. 50(9): 51-58.

Bumgardner, M., D. Nicholls and V. Barber. 2009. Charactermarked furniture made from red alder harvested in southeast Alaska: Product perspectives from consumers and retailers. Can. J. For. Res. 39(12): 2450-2459.

Bumgardner, M., S. Bowe and J. Wiedenbeck. 2013. Assessing the influence of forest ownership type and location on roundwood utilization at the stump and top in a region with small-diameter markets. Can. J. For. Res. 43: 376-384.

Bumgardner, M., B. Hansen, A. Schuler and P. Araman. 2001a. Options for small-diameter hardwood utilization: Past and present. In: M.H. Pelkki. Proceedings of the Annual Meeting of the Southern Forest Economics Workers (SOFEW), Lexington, KY, 26-28 May 2000. pp. 1-7.

Bumgardner, M.S., R.J. Bush and C.D. West. 2001b. Knots as an incongruent product feature: A demonstration of the potential for character-marked hardwood furniture. J. I. Wood Sci. 15(6): 327-336.

Bumgardner, M.S, R.J. Bush and C.D. West. 2001c. Product development in large furniture companies: A descriptive model with implications for character-marked products. Wood Fiber Sci. 33(2): 302-313.

Burdell, C. 1988. Crossties and other treated hardwood products. In: Proceedings of the Sixteenth Annual Hardwood Symposium, Cashiers, NC, 15-18 May 1988. pp. 165-167. Hardwood Research Council, Memphis, TN.

Bush, R.J., J.J. Bejune, B.G. Hansen and P.A. Araman. 2002. Trends in the use of materials for pallets and other factors affecting the demand for hardwood products. In: Proceedings of the 30th Annual Hardwood Symposium, Fall Creek Falls, TN, May 30-June 1, 2002. pp. 76-81. National Hardwood Lumber Association, Memphis, TN.

Chen, T. 2012. A study of the physical characteristics and psychological images of select Taiwanese hardwoods. Forest Prod. J. 62(1): $18-24$.
Choong, E.T, F.O Tesoro and F.G. Manwiller. 1974. Permeability of twenty-two small diameter hardwoods growing on southern pine sites. Wood Fiber Sci. 6(1): 91-101.

Christoforo, J.C., R.J. Bush and W.G. Luppold. 1994. A profile of the U.S. pallet and container industry. Forest Prod. J. 44(2): 9-14.

Clement, C., R. Beauregard, R. Gazo and T. Lihra. 2004. Correspondence analysis as a tool towards optimizing the use of white birch in the panel industry. Wood Fiber Sci. 36(4): 598-610.

Conners, T. 2008. Producing and inspecting railroad crossties. University of Kentucky - College of Agriculture, Cooperative Extension Service, Lexington, KY. Publication FOR-108.

Craft, E.P. and J.E. Baumgras. 1978. Products derived from thinning two hardwood timber stands in the Appalachians. Research Paper NE-422. USDA Forest Service, Broomall, PA. 8 p.

Craft, E.P. and D.M. Emanuel. 1981. Yield of pallet cants and lumber from hardwood poletimber thinnings. Research Paper NE-482. USDA Forest Service, Broomall, PA. 6 p.

Cumbo, D., R.L. Smith and P.A. Araman. 2003. Low-grade hardwood lumber production, markets, and issues. Forest Prod. J. 53(9): $17-24$.

Cumbo, D.W., R.L. Smith and C.W. Becker, III. 2004. Value analysis of lumber produced from small-diameter timber. Forest Prod. J. 54(10): 29-34.

Cutter, B.E., M.V. Coggeshall, J.E. Phelps and D.D. Stokke. 2004. Impacts of forest management activities on selected hardwood wood quality attributers: A review. Wood Fiber Sci. 36(1): 84-97.

Donovan, G.H. and D.L. Nicholls. 2003. Consumer preferences and willingness to pay for character-marked cabinets from Alaska birch. Forest Prod. J. 53(11/12): 27-32.

Dunn, M.A., R.P. Vlosky and T.F. Shupe. 2000. The pallet industry in the southern United States. Forest Prod. J. 50(10): 30-34.

Eads, L.D. 1967. Furniture species: A forecast of tomorrow's trends. Forest Prod. J. 17(8): 10-11.

Emanuel, D.M. 1983. Comparison of lumber values for grade-3 hardwood logs from thinnings and mature stands. Research Paper NE-529. USDA Forest Service, Broomall, PA. 4 p.

Fajvan, M.A., S.T. Grushecky and C.C. Hassler. 1998. The effects of harvesting practices on West Virginia's wood supply. J. Forest. 96(5): 33-39.

Floyd, D.W., B.D. McCoy and S.M. Bratkovich. 1993. Ohio's pallet industry. Forest Prod. J. 43(3): 59-63.

Fraser, R.F., W.W. Johnson and P.R. Blankenhorn. 1990. A description of the 1986 pallet manufacturing industry in Pennsylvania. Forest Prod. J. 40(6): 43-47.

Gephart, J.S., H.D. Petersen and S.M. Bratkovich. 1995. Green dimensioning: A review of processing, handling, drying, and marketing. Forest Prod. J. 45(5): 69-73.

Grushecky, S.T. and C.C. Hassler. 2012. Economics of merchandising pulpwood in West Virginia. Wood Fiber Sci. 44(3): 298-309.

Hamner, P., M.S. White and P.A. Araman. 2006. The effect of curve sawing two-sided cants from small diameter hardwood sawlogs on lumber and pallet part yields. Forest Prod. J. 56(10): 80-85.

Hardwood Market Report. 2009. 2008: The year at a glance. Hardwood Market Report, Memphis, TN. 78 p.

Hassler, C.C., J.J. Slahor and D.J. Gardner. 1999. A comparison of the treatability of southern yellow pine to five Appalachian hardwoods. Forest Prod. J. 49(2): 89-93.

Hubbe, M.A. and U. Buehlmann. 2010. A continuing reverence for wood. BioResources. 5(1): 1-2.

Huyler, N.K. and T.L. Turner. 1993. Quality wood from underutilized trees. North. J. Appl. Forest. 10(2): 95-97.

Jackson, G., J. Howard and A.L. Hammett. 2001. Use and production of solid sawn timbers in the United States. Forest Prod. J. 51(7/8): 23-28. 
Jahn, L., M. Bumgardner, C. Forbes and C. West. 2001. Consumer perceptions of character marks on cabinet doors. North Carolina State University, Cooperative Extension, Raleigh, NC. Paper AG617.

Jonsson, O., S. Lindberg, A. Roos, M. Hugosson and M. Lindstrom. 2008. Consumer perceptions and preferences on solid wood, wood-based panels, and composites: A repertory grid study. Wood Fiber Sci. 40(4): 663-678.

Knudson, R. and G. Brunette. 2015. Evaluation of Canadian prairie-grown hybrid poplar for high value solid wood products. Forest. Chron. 91(2): 141-149.

Koch, P. 1982. Non-pulp utilization of above-ground biomass of mixed-species forests of small trees. Wood Fiber Sci. 14(2): 118-143. Koch, P. 1985. Utilization of hardwoods growing on southern pine sites (Volume II: Processing). Agriculture Handbook No. 605. USDA Forest Service, Washington, DC. pp.1419-2542.

Leopold, A. 1928. The home builder conserves: One-third of our wood waste in home building may be saved by close utilization. Am. Forests. May: 276-278, 297.

Lihra, T., U. Buehlmann and R. Beauregard. 2008. Mass customization of wood furniture as a competitive strategy. Int. J. Mass Customization. 2(3/4): 200-215.

Lin, W., D.E. Kline and P.A. Araman. 1994. Dimension yields from factory grade 2 and 3 red oak logs. Forest Prod. J. 44(9): 19-25.

Lin, W., D.E. Kline, P.A. Araman and J.K. Wiedenbeck. 1995a. Producing hardwood dimension parts directly from logs: An economic feasibility study. Forest Prod. J. 45(6): 38-46.

Lin, W., D.E. Kline, P.A. Araman and J.K. Wiedenbeck. 1995b. Design and evaluation of log-to-dimension manufacturing systems using system simulation. Forest Prod. J. 45(3): 37-44.

Luppold, W. and M. Bumgardner. 2003a. How do we define hardwood quality and how does quality relate to value? In: G.S. Amacher and J. Sullivan. Proceedings of the 2002 Southern Forest Economics Workshop. Virginia Beach, VA, 17-19 May 2002. pp. 226-234.

Luppold, W. and M. Bumgardner. 2003b. What is low-value and/or low-grade hardwood? Forest Prod. J. 53(3): 54-59.

Luppold, W. and D. Alderman. 2007. Influence of species on site selection and timber removal: A case study for West Virginia. North. J. Appl. Forest. 24(2): 146-148.

Luppold, W. and M. Bumgardner. 2008. Forty years of hardwood lumber consumption: 1963 to 2002. Forest Prod. J. 58(5): 6-12.

Luppold, W.G. and M.S. Bumgardner. 2009. The wood household furniture and kitchen cabinet industries: A contrast in fortune. Forest Prod. J. 59(11/12): 93-99.

Luppold, W.G. and G.W. Miller. 2014. Changes in eastern hardwood sawtimber growth and harvest. Forest Prod. J. 64(1/2): 26-32. Luppold, W.G. and S. Pugh. (In press). The diversity of the eastern hardwood resource and how this diversity influences timber utilization. Forest Prod. J.

MacCleery, D.W. 1996. American forests: A history of resiliency and recovery. Forest History Society, Durham, NC. 58 p.

Marchal, R. and F. Mothe. 1994. Appreciation du bois de chene (Quercus robur L, Quercus petraea Liebl) par les consommateurs et les professionnels francais du bois. Ann. Sci. Forest. [now Annals of Forest Science]. 51(3): 213-231.

McCay, T.D. and H.W. Wisdom. 1984. Feasibility of small mill investments for utilizing small-diameter hardwood from coal lands in southwestern Virginia. Forest Prod. J. 34(6): 43-48.

McCurdy, D.R. and J.E. Phelps. 1992. Trends in the U.S. pallet industry: 1980, 1985, 1990. Forest Prod. J. 42(1): 25-28.

McCurdy, D.R., J.T. Ewers, F.H. Kung and D.B. McKeever. 1988. A study of lumber use in pallets manufactured in the United States: 1982 and 1985. Forest Prod. J. 38(2): 11-15.

McDonald, K.A., C.C. Hassler, J.E. Hawkins and T.L. Pahl. 1996. Hardwood structural lumber from log heart cants. Forest Prod. J. 46(6): 55-62.
Michael, J.H. 1997. A characterization of the Texas pallet industry. Forest Prod. J. 47(2): 27-30.

Mitchell, H.L., M.S. White, P.A. Araman and P. Hamner. 2005. Hardwood pallet cant quality and pallet part yields. Forest Prod. J. 55(12): 233-238.

National Hardwood Lumber Association (NHLA). 1994. Rules for the measurement and inspection of hardwood \& cypress. National Hardwood Lumber Association: Memphis, TN. 124 p.

National Hardwood Lumber Association (NHLA). 2014. Rules for the measurement and inspection of hardwood \& cypress. National Hardwood Lumber Association: Memphis, TN. 100 p.

Nicholls, D.L. and V. Barber. 2010. Character-marked red alder lumber from southeastern Alaska: Profiled panel product preferences by residential consumers. Forest Prod. J. 60(4): 315-321.

Nicholls, D.L., G.H. Donovan and J. Roos. 2004a. Consumer preferences for kitchen cabinets made from red alder: A comparison to other hardwoods. Wood Fiber Sci. 36(3): 432-442.

Nicholls, D., D. Parrent and K.J. Pavia. 2004b. The potential for developing alternate grading rules for birch lumber in Alaska. Forest Prod. J. 54(2): 57-60.

Nicholls, D., M. Bumgardner and V. Barber. 2010a. Consumer and manufacturer perceptions of hardwood panels made from character-marked lumber. Int. Wood Prod. J. 1(1): 28-34

Nicholls, D., M. Bumgardner and V. Barber. 2010b. Edge-glued panels from Alaska hardwoods: Retail manager perspectives. Gen. Tech. Rep. PNW-GTR-809. Portland, OR: U.S. Department of Agriculture, Forest Service, Pacific Northwest Research Station. 14 p.

Nicholls, D.L., J.W. Funck, C.C. Brunner and J.E. Reeb. 2009. Influence of edging practices on cutting yields of Alaska birch lumber. Forest Prod. J. 59(1-2): 29-34.

Nordvik, E. and N.O. Broman. 2007. Comparison of visual properties in digital wood images. Forest Prod. J. 57(1-2): 97-102.

Nyrud, A.Q. and T. Bringslimark. 2010. Is interior wood use psychologically beneficial? A review of psychological responses toward wood. Wood Fiber Sci. 42(2): 202-218.

Ozanne, L.K. and P.M. Smith. 1996. Consumer segments for environmentally marketed wooden household furniture. Wood Fiber Sci. 28(4): 461-477.

Pakarinen, T.J. and A.T. Asikainen. 2001. Consumer segments for wooden household furniture. Holz als Roh-und Werkstoff. 59: 217-227.

Perkins, B., R.L. Smith and B. Bond. 2008a. Case study of the economic feasibility of a red oak small-diameter timber sawmill and pallet-part mill. Wood Fiber Sci. 40(2): 258-270.

Perkins, B., R.L. Smith and P.A. Araman. 2008b. Analyzing the feasibility of utilizing small diameter hardwood timber for solid wood products and residues. General Technical Report SRS-111. USDA Forest Service, Asheville, NC. 6 p.

Perkins, B., R.L. Smith and B. Bond. 2008c. Solid wood and residue yield analysis of small-diameter red oak logs. Forest Prod. J. 58(1/2): 97-100.

Phelps, J.E. and D.R. McCurdy. 1993. Railroad tie production in the United States, 1991. Forest Prod. J. 43(3): 15-18.

Quesada-Pineda, H., S. Sanchez-Gomez and P.A. Araman. 2012. A quantitative study of the U.S. wood pallet industry based on supply chain management practices. J. Appl. Packaging Res. 6(1): 1-26. Rast, E.D., D.L. Sonderman and G.L. Gammon. 1973. A guide to hardwood log grading. General Technical Report NE-1. USDA Forest Service, Upper Darby, PA. 32 p.

Rosen, H.N., H.A. Stewart and D.J. Polak. 1980. Dimension yields from short logs of low-quality hardwood trees. Research Paper NC184. USDA Forest Service, St. Paul, MN. 22 p.

Reynolds, H.W. and C.J. Gatchell. 1970. The SHOLO mill: Make pallet parts and pulp chips from low-grade hardwoods. Research Paper NE-180. USDA Forest Service, Upper Darby, PA. 16 p. 
Reynolds, H.W. and C.J. Gatchell. 1979. Marketing low-grade hardwoods for furniture stock-a new approach. Research Paper NE-444. USDA Forest Service, Broomall, PA. 7 p.

Reynolds, H.W., P.A. Araman, C.J. Gatchell and B.G. Hansen. 1983. System 6 used to make kitchen cabinet C2F blanks from small-diameter, low-grade red oak. Research Paper NE-525. USDA Forest Service, Broomall, PA. 11 p.

Robinson, S.C., D. Tudor and P.A. Cooper. 2011. Feasibility of using red pigment producing fungi to stain wood for decorative applications. Can. J. For. Res. 41(8): 1722-1728.

Scholl, M.S., J.K. Wiedenbeck, P.R. Blankenhorn, C.D. Ray, L.R. Stover and B.W. Beakler. 2008. A comparison of kiln-drying schedules and quality outcomes for 4/4-thickness black cherry lumber sawn from small-diameter logs. Forest Prod. J. 58(12): 41-48.

Schuler, A., M. Bumgardner, B. Hansen and B. Luppold. 2001. Species shift: implications of the rising use of hardwoods in OSB. Engineered Wood J. 4(2): 29-32.

Scholz, S.W. and R. Decker. 2007. Measuring the impact of wood species on consumer preferences for wooden furniture by means of the Analytic Hierarchy Process. Forest Prod. J. 57(3): 23-28.

Serrano, J.R. and D. Cassens. 1998. Dimensional stability of red oak panels produced from small-diameter top logs. Forest Prod. J. 48(7/8): 71-74.

Serrano, J.R. and D. Cassens. 2000. Pallet and component parts from small-diameter red oak bolts. Forest Prod. J. 50(3): 67-73.

Shigo, A.L. and W.E. Hillis. 1973. Heartwood, discolored wood, and microorganisms in living trees. Annu. Rev. Phytopathol. 11: 197-222.

Smith, P.A. 1991. The Washington state wood pallet industry. Forest Prod. J. 41(5): 39-44.

Smith, R.L., W. Pohle, P.A. Araman and D. Cumbo. 2004. Characterizing the adoption of low-grade hardwood lumber by the secondary wood processing industry. Forest Prod. J. 54(12): 15-23.
Smith, W.B., H.O. Canham, J. Harris, E.F. Neuhauser and A. Smith. 1996. Economic analysis of producing red oak dimension squares with a radio-frequency vacuum dry kiln. Forest Prod. J. 46(3): 30-34.

Solomon, M.R. 1988. Building up and breaking down: The impact of cultural sorting on symbolic consumption. In: Research in Consumer Behavior, E. Hirschman and J. Sheth, eds. JAI Press, Greenwich, CT. pp. 325-351.

Sonti, S.S., J.F. Davalos, M.G. Zipfel and H.V.S. Gangarao. 1995. A review of wood crosstie performance. Forest Prod. J. 45(9): 55-58.

Stumbo, D.A. (ed.). 1981. Utilization of low-grade southern hardwoods: Feasibility studies of 36 enterprises (Proceedings). Forest Products Research Society, Madison, WI. 289 p.

Swearingen, K.A., E.N. Hansen and J.E. Reeb. 1998. Customer preference for Pacific Northwest hardwoods. Forest Prod. J. 48(2): 29-33.

Thiel, M., N. Basiliko, J. Caspersen, J. Fera and T. Jones. 2015. Operational biomass recovery of small trees: Equations for six central Ontario tree species. Can. J. For. Res. 45(3): 372-377.

Wang, Q., G. Shi and C. Chan-Halbrendt. 2004. Market potential for fine furniture manufactured from low-grade hardwood: Evidence from a conjoint analysis in the northeastern United States. Forest Prod. J. 54(5): 19-25.

Wu, J., J. Wang and J. McNeel. 2011. Economic modeling of woody biomass utilization for bioenergy and its application in central Appalachia, USA. Can. J. For. Res. 41(1): 165-179.

Wiedenbeck, J., M. Wiemann, D. Alderman, J. Baumgras and W. Luppold. 2004. Defining hardwood veneer log quality attributes. General Technical Report NE-313. USDA Forest Service, Newtown Square, PA. 36 p. 